\title{
Strategic Priorities of Development of Agro- industrial Complex of the Problem Region of Russia
}

\author{
Alexander Alexandrovich Mokrushin \\ Economy and Management Department \\ Adyghe State University \\ Maikop, Russia \\ E-mail: mokrushin_alex@inbox.ru
}

\author{
Saida Aslanovna Khatukay \\ Economy and Management Department \\ Adyghe State University \\ Maikop, Russia \\ E-mail: sa_khatukay@mail.ru
}

\author{
Aslan Alievich Tamov \\ Economy and Management Department \\ Adyghe State University \\ Maikop, Russia \\ E-mail: tamov@mail.ru \\ Bella Ibragimovna Khutyz \\ Economy and Management Department \\ Adyghe State University \\ Maikop, Russia \\ E-mail: hbella@mail.ru
}

\begin{abstract}
The article reveals the aspects of strategic priorities of socio-economic development of the agro-industrial complex substantiation in the problem (budget-deficit) region. Territorial and sectoral features of the agro-industrial complex of the Republic of Adygea, belonging to the group of problem regions of the South of Russia, are highlighted. The priority directions of strategic development of the agro-industrial complex of the Republic of Adygea, based on its key competitive advantages and taking into account the territorial and sectoral features, are substantiated. Promising instruments of state support and regulation of economic processes in the agro-industrial complex of the problem are highlighted. Special attention is paid to the possibilities of program-target planning of the development of the agro-industrial complex of the problem region. The key organizational and methodological problems of the development and implementation of target programs for the development of agro-industrial complex of the Republic of Adygea are revealed.
\end{abstract}

Keywords-strategic priorities; agro-industrial complex; problem region; territorial and sectoral features; instruments; cluster

\section{INTRODUCTION}

In conditions of uneven development of Russian agriculture regions and the tightening of inter-regional competition the efficiency of the agribusiness development depends on the formulation and implementation of regional development strategies. Strategic management of territorial agriculture is aimed at effective use of production factors, ensuring food security of the country. Strategic planning of territorial agriculture development allows adapting the regional economy to the action of external systemic factors, to integrate regional strategies and national strategy, contributing to the consolidation of resources, management initiatives at different levels. At the same time, strategic guidelines for the regional agriculture development create the opportunity to improve the planning system at the microlevel of management of business entities. These circumstances actualize scientific researches of strategic priorities, problems of elaboration of social and economic development strategy for agro-industrial complex of Russian regions.

\section{TERRITORIAL AND SECTORAL FEATURES OF THE}

\section{AGRO-INDUSTRIAL COMPLEX OF THE PROBLEM REGION}

The characteristic features of the agro-industrial complex of the problem region, predetermining the specifics of strategic planning of economic processes, include the following:

- deformed structure of production; long-term lack of decisions on the structural organization of agri-food subcomplexes of the region, on effective state regulation of the proportions of inter-sectoral exchange in AIC, regulation of the competitive environment of the markets of agricultural products, raw materials and food in the region;

- disintegration of traditional inter-economic, intersectoral relations in the territorial agro-industrial complex;

- low level of the production infrastructure development in the agro-industrial complex of the region;

- extensive character of reproduction in the branches of agriculture, food industry of the region;

- absence of possibility of formation of financial and economic base for stable social and economic development of the region in the conditions of considerable budget deficit and dependence on Federal financing. 
the leading agricultural enterprises of the region to more capacious external markets;

- low-level development of agromarketing in agricultural entities; lack of territorial brand of food products;

- insufficient level of intraregional scientific and technical support of agricultural production.

The structure of agricultural production by categories of farms of the Republic of Adygea is characterized by heterogeneity. The feature of the structural organization of agriculture of the Republic of Adygea is also the dominance of small forms of agribusiness, characterized by extensive type of production and limited resources.

\section{STRATEGIC PRIORITIES OF ECONOMIC DEVELOPMENT OF AGRO-INDUSTRIAL COMPLEX OF THE REPUBLIC OF \\ ADYGEA}

The key tasks of strategic management of regional agro-industrial complex in contemporary Russia include the following [1], [2]:

- improvement the competitiveness of agro-industrial production in the region;

The high-level development of grain production in the Republic of Adygea is largely due to the qualitative characteristics of land resources, as well as the intensification of agricultural production (the size of fertilizers, land cultivation technologies used, cultivated varieties of grain crops). At the same time, there is a positive trend of growth in the yield of grain crops in the farms of the Republic of Adygea.

The characteristic features of the agro-industrial complex of the Republic of Adygea as one of the problem (budgetdeficit) regions of the South of Russia include the following:

- maintenance of the structural imbalance in the level of development of the enterprises of the agroindustrial complex, large share of small agribusiness in the structure of regional agro-industrial complex; high price disparity in the regional agro-industrial complex maintaining;

- deep differentiation of districts by the level of development of agricultural enterprises;

- shortage of agricultural cooperatives and vertically integrated agricultural corporations; underdevelopment of agricultural cooperation and vertical integration in the region;

- low-level of state subsidies to agricultural producers in the region; low-level competition in local agri-food markets;

- lack of effective state structural policy and experience in the implementation of public-private partnership (PPP) projects in the agro-industrial complex of the region;

- the presence of developed foreign trade relations of agricultural enterprises of the region; orientation on
- development of industrial, social infrastructure of the rural territory; developing of competitive environment of agri-food market of the region, institutional and economic environment of intersectoral exchange;

- improvement of the management system of economic processes in the agro-industrial complex of the region by combining market and state mechanisms, the development of public-private partnerships;

- implementation of modern organizational models of inter-firm, inter-sectoral cooperation between economic entities of the regional agro-industrial complex;

- development of digitalization processes in regional agro-industrial complex.

Strategic development of agro-industrial complex in the problem region should be consistent with the following Russian modernization priorities [3], [4]:

- improvement of budget supporting system;

- ensuring scientific and technological development of agriculture, including institutional modernization of agriculture, the growth of budget support for agricultural science;

- development and implementation of an effective structural policy, including the improvement of the sectoral structure, optimization of the placement of agriculture and processing industry, the development of small business in agriculture;

- development of agricultural cooperation and vertical integration in agro-industrial complex; 
- ensuring of integrated development of rural areas of contemporary Russia.

Competitive advantages, disadvantages, opportunities and limitations of strategic development of agro-industrial complex of the Republic of Adygea are presented in "Table I".

TABLE I. SWOT-ANALYSIS OF THE AGRO-INDUSTRIAL COMPLEX OF THE REPUBLIC OF ADYGEA

\begin{abstract}
Strengths (S)
$\mathrm{S} 1$ - favorable climatic conditions, high quality characteristics of the soil;

S2 - active state support of small forms of agribusiness (within the framework of the State target program "Development of agriculture and regulation of agricultural products, raw materials and food markets" for 2013-2020");

S3 - priority character of dairy, grain, fruit and vegetable subcomplexes in the strategic development of the region;

$\mathrm{S} 4$ - high yield of grain crops in the Republic of Adygea.
\end{abstract}

\section{Opportunities $(\mathbf{O})$}

$\mathrm{O} 1$ - possibility of integration developing between agro-industrial enterprises of Adygea and other regions of the South of Russia;

$\mathrm{O} 2$ - realization of competitive advantages of grain production, vegetable growing, horticulture of the Republic of Adygea;

$\mathrm{O} 3$ - conditions of the Russian food embargo; implementation of the

state policy of import substitution in the markets of agricultura products, food;

$\mathrm{O} 4$ - regional administration activity in attracting large corporate investors, in providing preferential business conditions;

O5 - possibilities of structural reorganization of agro-industrial complex; investment reorientation to horticulture, vegetable growing branches.

$\mathrm{W} 1$ - imbalances in branch development in regional agro-industrial complex; intersectoral disparity of prices in agriculture;

W2 - large corporate structures shortage; vertically integrated agricultural holdings shortage;

W3 - small forms of agribusiness domination in different branches of regional agriculture;

W4 - low-level development of cooperation and integration in the regional agro-industrial complex;

W5 - low-level investment attractiveness of the regional agroindustrial complex with a significant deficit of state subsidies for agribusiness;

W6 - imbalance in the level of interregional commodity turnover of raw materials, food.

T1 - reduction of state support programs financing; reduction of investments in agriculture in the region;

$\mathrm{T} 2$ - growth of interest rates on loans, tax rates, customs duties;

T3- threats of cancellation of counter-sanctions and restrictions on fruits and vegetables imports;

$\mathrm{T} 4$ - risk of recession of the Russian economy in the conditions of unfavorable market conditions of hydrocarbon raw materials and the effects of sectoral sanctions of the EU;

$\mathrm{T} 5$ - risk of outflow of qualified labor resources from the Republic of Adygea.

In the conditions of prolonged financial and economic crisis, the main limitations of the strategic development of agro-industrial complex in the Adygea include the following:

- extensive type of reproduction in the agricultural sector of the region;

- low-level development of competitive environment in agricultural raw materials and food regional markets;

- structural imbalances in the level of development of agricultural, processing, supply and marketing enterprises, farms in the agro-industrial complex of the region;

- disproportionate development of industries, sectors of agriculture in the region;

- shortage of large and medium-sized businesses in AIC, the preservation of unequal cross-sectoral exchange in the regional agro-industrial complex.

The following priority development directions of agroindustrial complex of Adygea were identified based on SWOT-analysis and regional competitive advantages investigation:

- diversification of the regional agro-industrial complex through the development of production of high- margin agricultural products, the development of ecologically clean production;

- structural modernization of plant growing and farming: development of intensive gardening, grain and leguminous crops producing, target development of agricultural rice producing, increasing of capacities for storage, primary processing of agricultural crops (including trade and logistics centers on the basis of public-private partnership mechanisms);

- development of large-scale dairy cattle breeding as a system-forming sub-sector of agriculture of the Republic of Adygea; development of promising areas of animal husbandry in small forms of agribusiness as an alternative to pig farming;

- the cluster model implementation for structural modernization of the regional agro-industrial complex including creation of agro-industrial cluster consisting of agro-food subcluster and meat-milk subcluster;

- development of management structures of territorial agribusiness through the creation of a Project office for the development of agribusiness in the region; the development of regional institutions, associations, 
time, in many regions of Russia, including the Republic of Adygea, there is no approved strategy for the development of agro-industrial complex.

The effectiveness of the strategy for the development of territorial agro-industrial complex depends largely on the instruments used. Target programs, investment projects, investment platforms and strategic events remain the most common instruments for the implementation of strategies and strategic priorities for the development of agriculture in Russia's regions. At the same time, there is a lack of organizational structure to manage the implementation of the strategy for the development of territorial agro-industrial complex, as well as the absence of a mechanism for monitoring and correcting strategic priorities.

The State program "Development of agriculture and regulation of markets of agricultural products, raw materials and food" for 2013-2020 has been implementing in the territory of the Republic of Adygea and including the following sub-programs:

- sub-program "Development of branches of agroindustrial complex";

- sub-program "Stimulation of investment activities in the agro-industrial complex";

- sub-program "Development of agricultural land reclamation";

- sub-program "Sustainable development of rural areas for 2014-2017 and for the period up to 2020 in the Republic of Adygea".

The main measures of state supporting in agro-industrial complex of the Republic of Adygea in the framework of the subprogram "development of agricultural industries" include the following:

- reimbursement of the costs of laying and care of perennial fruit and berry plantations (M 1);

- state support of the profitability of agricultural producers by costs subsidizing (M 2);

- state support of novice farmer (M 3);

- development of family livestock farms on the basis of peasant (farm) (M 4);

- risk reduction in the sub-sectors of crop production (M 5);

- reimbursement of part of the interest rate on shortterm loans for processing of crop and livestock products (M 6);

- reimbursement of part of the interest rate on shortterm loans for the development of dairy cattle (M 7);

- reimbursement of part of the interest rate on shortterm loans for the development of livestock, processing and sale of livestock products (M 8);

- development of beef cattle breeding (M 9);

Law of the Republic of Adygea "On strategic planning in the Republic of Adygea” (dated 06.05.2015 № 455). At the same 
In accordance with the presented strategic priorities for

- development of dairy cattle breeding (M 10);

- stimulation of development of sheep and goat breeding (M 11);

- state support of livestock breeding (M 12);

- development of elite seed production (including reimbursement of part of the costs for the purchase of elite seeds) (M 13) ("Fig. 1").

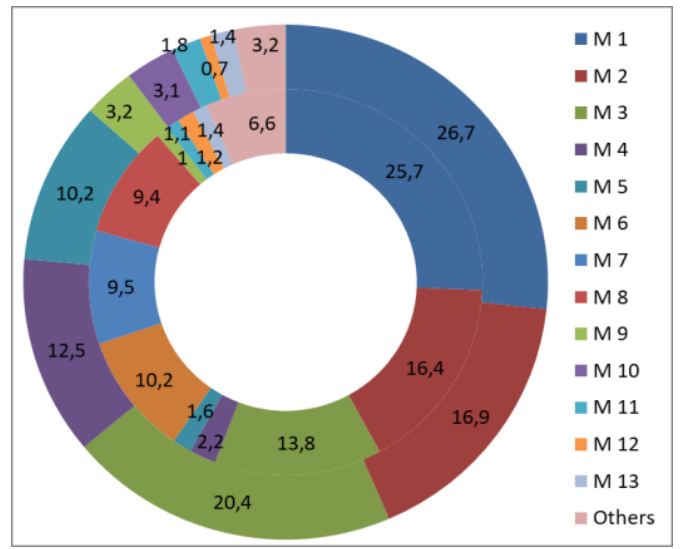

Fig. 1. Funding structure of activities under the target subprogram "Development of agriculture" of the Republic of Adygea in 2017-2018, \%.

The studies revealed a close relationship between the level of state subsidies for agricultural production and the increase in production. State subsidies as the main instrument of state support of the agricultural sector of the region's economy have a decisive impact on the performance of the agro-industrial complex of the Republic of Adygea.

Evaluation of the results of the program-target state support of agro-industrial complex in the Republic of Adygea indicates the following organizational and methodological problems in the development and implementation of departmental target programs [5]:

- insufficient level of integration of state programs into the regional budget process;

- shortage of indicators to assess the implementation of state target programs;

- non-compliance with the requirements for the content of state programs in Republic of Adygea; shortcomings in reporting on state target programs;

- the lack of sufficient experience in program-target planning of regional agro-industrial complex; gaps in the legal regulatory framework for program-target planning in the region.

The main development directions of state program-target planning of economic processes in the regional agroindustrial complex include the following: increase of quality requirements to the content of state programs; scientific substantiation of indicators for evaluation of state target programs implementation; increasing the level of integration of government programs [6], [7]. the development of agro-industrial complex of the Republic of Adygea, the following promising instruments of state support and regulation of economic processes are in demand:

- instruments to improve the management structures of territorial agro-industrial complex, innovative regional institutions, associations including center for cluster development of the region, regional Agency for economic development, technology transfer centers, the Agency for advanced innovations, Corporation for regional social-economic development, investment sites, Project office for the development of agriculture in the region etc.;

- traditional instruments of state stimulation of reproductive processes in the regional agriculture for new objects (clusters, subregional localities) (e.g., the program of creation and development agro-industrial cluster etc.);

- instruments of state monitoring and control over the implementation of the strategic development plan of the regional agro-industrial complex.

In modern conditions, the formation of institutions for the development of territorial agro-industrial complex should be focused on the use of new sources, schemes of project financing, public-private partnership models. There is also a demand for improvement of legislation to stimulate investment activity in the agro-industrial complex of problem regions, as well as the development of small forms of agribusiness.

\section{CONCLUSION}

The strategic directions of socio-economic development of agro-industrial complex of the Republic of Adygea include the following: forming and developing of agri-food cluster; forming of multilevel system of agricultural consumer cooperation; implementing of infrastructure PPPprojects for the development of elevators, milling facilities; increasing of state support for small forms of agribusiness, agricultural cooperatives, including state co-financing of business-projects; developing of innovative activity of agricultural enterprises.

The prospects of strategic development of the regional agro-industrial complex are largely associated with the involvement of agro-industrial corporations, the implementation of public-private partnership projects. The implementation of the presented strategic priorities is aimed at increasing competitiveness, structural modernization of the agro-industrial complex of the problem region, effective implementation of its resource potential. At the same time, the potential of both traditional program-target instruments and new territorial development institutions is in demand.

\section{REFERENCES} management of competitiveness," Regional agro-systems: Economics and sociology. 2016. No. 1, p. 1.
[1] A. A. Anfinogentova, "Agro-industrial complex of Russia: strategic 
[2] I. G. Ushachev, A. F. Serkov, V. V. Maslova, V. S. Chekalin, "Actual directions of improvement of agrarian policy of Russia," AIC: Economics and management, 2019, No. 3, pp. 4-16.

[3] A. A. Tamov, R. R. Avanesova, "Food market of the region as an object of strategic management" The Bulletin of the Adyghe State University. Series "Economics", 2010, Issue 3, pp. 67.

[4] I. G. Ushachev, V. S. Chekalin, "Modern tendencies and prospects of development of agroindustrial complex of Russia," Standards and quality, 2019, No. 8, pp. 80-84.

[5] A. A. Mokrushin, "Program-target instruments of state regulation of the agro-industrial complex of the problem region," The Bulletin of the Adyghe State University. Series "Economics", 2017, Issue 3 (205), pp. 43-55.

[6] V. I. Nechaev, Yu. I. Bershitsky, S. M. Reznichenko, Regional aspects of state regulation of agro-industrial production. St. Petersburg: LAN, 2009. $336 \mathrm{p}$.

[7] V. Z. Mazloev, M. G. Ozerova "Formation of transformation processes of the economic mechanism of the agricultural sector," Economics of agriculture of Russia, 2017, No. 8, pp. 15-21. 